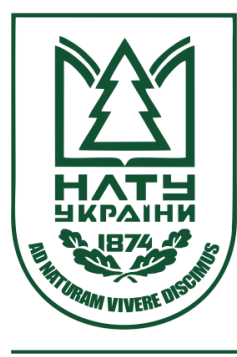

Науковий вісник НлтУ України Scientific Bulletin of UNFU

(CC) (i) ISSN 1994-7836 (print)

https://nv.nltu.edu.ua

https://doi.org/10.15421/40280918

BY ISSN 2519-2477 (online)

Article received 30.07.2018 p.

Article accepted 25.10.2018 p.

@ Correspondence author

M. K. Rusynko

удк 519.86:330.322

М. К. Русинко, Т. М. Костирко

Львівський навчально-науковий інститут ДВНЗ "Університету банківської справи", м. Львів, Украӥна

\title{
МОДЕЛЮВАННЯ ІНВЕСТИЦІЙНОЇ ПОЛІТИКИ БАНКУ МЕТОДАМИ НЕЧІТКОЇ ЛОГІКИ
}

Проаналізовано моделі, які використовують в банківській діяльності, починаючи від робіт Еджворта до моделей нечіткої логіки. Зазначено їх переваги та недоліки. Обгрунтовано вибір моделі нечіткої логіки як інструменту моделювання. Розглянуто задачу оцінки інвестиційної політики банку, для якої визначено вид функції приналежності, що є одним із найважливіших питань у теорії нечітких множин. За функцію приналежності обрано несиметричну функцію Гауса, що зумовлено специфікою побудови таких функцій економічних показників, для яких у багатьох випадках відомо тільки три значення: найімовірніше, максимально та мінімально можливі. Запропоновано використати несиметричну функцію приналежності, сформовану на основі функції Гауса з різними значеннями середньоквадратичного відхилення. Проведено чисельні експерименти оцінки інвестиційного проекту на основі трикутних функцій приналежності та запропонованих несиметричних гаусоїд. Для розрахунку параметрів несиметричної функції Гауса спочатку побудовано наближення - трикутна функція приналежності. Виходячи з параметрів трикутної функції, розраховано середньоквадратичні відхилення для лівої та правої частин функції Гауса. Показано, що під час використання несиметричної функції Гауса потрібні більші початкові інвестиції для того, щоб проект був прибутковим. Зроблено висновок щодо необхідності ретельного підбору виду функцій приналежності для зменшення інвестиційного ризику.

Ключові слова: чистий приведений дохід; альфа-рівні; несиметрична функція приналежності; інвестиції.

Вступ. Ефективне функціонування економіки України, темпи та масштаби їі інвестиційної активності певною мірою залежать від стану та розвитку вітчизняної банківської системи. В Україні управління банківським капіталом перебуває на етапі становлення і стикається 3 особливими труднощами, зумовленими незавершеністю економічних реформ, недосконалістю нормативно-правової бази, нерозвиненістю ринку капіталу тощо. За таких умов забезпечення ефективного управління банківським капіталом стає важливим завданням Національного банку України та національної економіки України. Багато питань, пов'язаних із забезпеченням ефективності управління капіталом вітчизняних банків, потребують поглибленого дослідження. Зокрема необхідне комплексне вирішення питань, пов'язаних з оцінкою процесів формування, використання та оптимізації капіталу банків, удосконалення механізму управління ним в умовах економічної нестабільності та обгрунтування напрямів підвищення їхньої капіталізації. При цьому варто враховувати, що економічне середовище постійно змінюється і ставить перед банківською системою щоразу нові завдання, що потребує зосередження уваги на їх вирішенні. Важливо зазначити, що в міжнародній практиці сучасна теоретико-методологічна база управління капіталом банків сформована на принципах Базельського комітету 3 питань банківського нагляду "Базель-3", які зосереджують увагу на посиленні стійкості банківської системи, збільшенні ліквідних резервів і поліпшенні якості капіталу.

Актуальність і необхідність поглибленого дослідження зазначених проблем зумовили вибір теми, мету і завдання нашого дослідження.

Мета роботи-побудова моделі оцінки інвестиційних проектів за допомогою несиметричних функцій приналежності на основі розподілу Гауса для методики альфа-рівнів нечіткої логіки та подальше її використання в аналізі інвестиційної діяльності банків.

Матеріали та методи дослідження. Ухвалення рішень щодо інвестиційної політики є одним із найважливіших етапів діяльності будь-якої компанії. Тому для ефективного використання залучених грошових коштів та отримання максимального ефекту від вкладення отримання максимального прибутку на вкладені інвестиції - необхідно провести ретельний аналіз грошових потоків, пов'язаних із реалізацією проекту.

Існує кілька методів оцінки привабливості інвестиційного проекту і кілька основних критеріїв вибору того чи іншого проекту (Eidinov, 2008; Zamkov, Tolstopiatenko \& Cheremnykh, 2001; Chetyrkin, 2004). В основі кожного методу закладено важливий принцип, відповідно до якого внаслідок реалізації проекту фірма повинна отримати прибуток (тобто повинен збільшитися власний капітал). При цьому фінансові показники характеризують проект із різних сторін відповідно до ін-

\section{Інформація про авторів:}

Русинко Моріка Костянтинівна, канд. фіз.-мат. наук, доцент, кафедра економіки та інформаційних технологій.

Email: morika.rusinko@gmail.com

Костирко Тарас Миколайович, аспірант, кафедра економіки та інформаційних технологій. Email: taraskostyrka@gmail.com

Цитування за ДСТУ: Русинко М. К., Костирко Т. М. Моделювання інвестиційної політики банку методами нечіткої логіки. Науковий вісник НЛтУ України. Серія Економічна. 2018, т. 28, № 9. С. 90-94

Citation APA: Rusynko, M. K., \& Kostyrko, T. M. (2018). Modeling of a bank investment strategy by Fuzzy logic's method. Scientific Bulletin of UNFU, 28(9), 90-94. https://doi.org/10.15421/40280918

90 Науковий вісник НлтУ України, 2018, т. 28, № 9 Scientific Bulletin of UNFU, 2018, vol. 28, no 9 
тересів зацікавлених осіб, пов'язаних із компанією (таких як кредитори, інвестори, менеджери).

Розглянемо ці методи їх переваги та недоліки. Банк $\epsilon$ складним механізмом, комплексне моделювання роботи якого $\epsilon$ надзвичайно складним завданням. У 1972 p. Мерфі писав, що важко створити інтегровану теорію банківської фірми, яка одночасно охоплювала б керування ліквідністю, вибором портфеля активів і політику ціноутворення (Murphy, 1972).

У роботі Еджворта (F. Edgeworth) "The Mathematical Theory of Banking" (1888 р.) запропоновано першу математичну теорію банківської справи, у якій автор чітко вказує на кількісні співвідношення між величиною зобов'язань банку і необхідним резервом ліквідності. Згідно 3 цією теорією, обсяг резервів необхідно збільшувати пропорційно квадратному кореню від зобов'язань банку (Newman, 1987). Модель належить до класу аналітичних моделей. Вперше інтуїція банкірів набула математичної форми. Однак перша теорія не охоплювала усього спектра банківської діяльності (Yankovskyi, 2008).

Нову спробу в моделюванні банківської діяльності здійснив I. Фішер (I. Fisher). У 1930 р. він висунув теорію на основі процентної ставки та приведеної вартості, основою якої $є$ детермінована модель 3 цільовою функцією максимізації чистої приведеної вартості. Модель $є$ однокритеріальною і враховує лише одну характеристику активів, а саме дохідність, Водночас не враховує ризики, які виникають під час проведення інвестиційної політики банку. Позитивним цієї моделі є використання простих математичних співвідношень, до негативних рис відносять не врахування в моделі чинника невизначеності, з яким стикаються у повсякденному житті банківські працівники.

Вперше кількісну оцінку ризику банківських операцій відображено у портфельній теорії Г. Марковіца (H. Markovitz). Модель Марковіца є більш складною, порівняно з існуючими на той час теоріями, і враховує два важливих чинника банківської діяльності-дохід і ризик, а також аналогічні характеристики портфеля активів. Недоліком цієї моделі можна вважати складний математичний апарат. Математична модель формування оптимального портфеля активів $є$ задачею квадратичної оптимізації (Yankovskyi, 2008).

Подальшого розвитку портфельна теорія Марковіца набула в моделі ринку капіталів, яку запропонував У. Шарп (W. Е. Sharpe). Від моделі квадратичної оптимізації У. Шарп перейшов до задачі лінійної оптимізації, що значно спростило задачу і дало змогу використовувати іiі і нині на фондових ринках усього світу під час вибору конкретних активів для формування портфеля інвестора.

Однак, окрім управління активами, діяльність банку зосереджена і на управлінні залученими засобами, а однокритеріальна модель ринку капіталу таку задачу не розв'язує.

Спробував розв'язати цю задачу Р. Портер (R. Porter). В основі його теорії закладено балансове рівняння:

$$
1+N=k+B+L,
$$

де: 1 - обсяг депозитів, що дорівнює $1 ; N$ - обсяг власного капіталу у відношенні до обсягу депозитів; $k$ - обсяг готівкових засобів і засобів на кореспондентських рахунках банку у відношенні до обсягу залучених депозитів, $0<k<1$; $B$ - обсяг цінних паперів, наданих бан- ком, у відношенні до обсягів залучених депозитів; $L-$ обсяг кредитів, виданих банком, у відношенні до обсягу залучених депозитів (Porter, 1961, pp. 331).

I хоча в моделі враховано обсяг пасивів, залучених банком, модель має більш теоретичне, ніж практичне значення для прийняття конкретних управлінських рішень для успішного функціонування банку.

Подальшим розвитком портфельної теорії Марковіца та моделі Портера можна вважати модель Кейна і Молкіла (Kane \& Malkiel, 1965). Цільова функція однокритеріальної моделі - максимізація доходу. Аргументами $\epsilon$ індекси дохідності портфеля активів, а також величина ризику, який обчислюють як середньоквадратичне відхилення дохідності портфеля активів банку. Також у моделі враховано кореляційний зв'язок між активами портфеля і використано балансове рівняння, аналогічне (1).

Однак модель не враховує активи у вигляді готівки в касі, засоби на кореспондентських рахунках в інших банках, ризики і структуру портфеля пасивів, видатки, які супроводжують пасивні операції банку, управління власним капіталом банку. Модель $є$ статичною (Yankovskyi, 2008).

У моделі одночасно розглянуто управління і зобов'язання банку для максимізації прибутку (Sinki, 1994). Невизначеність в моделі враховано у вигляді визначення депозитної та кредитної процентних ставок. Вперше введено зміну, яка характеризує надлишок або недостатність ліквідності. У моделі вперше розглянуто інструмент, який на практиці допомагає керувати ліквідністю.

До недоліків моделі відносять відсутність можливості керувати власним капіталом банку. Банк працює в умовах нестабільного зовнішнього середовища, в умовах стресу та невизначеності. За таких умов управлінському апарату часто необхідно приймати рішення, які неможливо описати методами класичної математики та теорії імовірності. Застосування ймовірнісних методів неефективне для описання суб'єктивних даних.

Інформаційні агентства, такі як Reuters, Bloomberg та інші, надають широкий спектр інструментів технічного аналізу фінансової інформації для прогнозування ринків цінних паперів на коротко- та середньострокову перспективи. Всі учасники мають доступ до цього інструментарію, однак випадки банкрутства не рідкість, причому причини банкрутства не можна описати ймовірнісними і строго математичними методами. Тому поряд із класичними математичними методами щоразу частіше для аналізу невизначеності застосовують методи нечіткої логіки (Yankovskyi, 2008).

До критеріїв, що використовують в аналізі інвестиційної діяльності (інтегральними показниками), відносять:

- чистий приведений дохід (Net Present Value, $N P V$ );

- термін окупності інвестицій (Payback Period, PP);

- внутрішня норма дохідності (Internal Rate of Return, IRR);

- модифікована внутрішня норма дохідності (Modified Internal Rate of Return, MIRR);

- рентабельність інвестицій (Profitability, $P$ );

- індекс рентабельності (Profitability Index, $P$ ).

Усі розрахунки показників ефективності (інтегральних показників) виконують 3 дисконтованими потоками готівки, що представляють надходження грошових коштів (Cash Inflows), і відтоки готівки або виплати 
грошових коштів (Cash Outflows) у процесі реалізації проекту.

Чистий приведений дохід $(N P V)$ - це різниця між теперішньою вартістю майбутнього грошового потоку i вартістю первинних фінансових інвестицій. Показник $N P V$ показує безпосереднє збільшення капіталу банку, тому для акціонерів він є найбільш значущим. Критерієм прийняття проекту є додатне значення $N P V$. У випадку, коли необхідно зробити вибір з кількох можливих проектів, перевагу потрібно надавати проекту 3 більшою величиною чистого приведеного доходу.

Водночас нульове або навіть від'ємне значення $N P V$ не свідчить про збитковість проекту як такого, а лише про його збитковості в разі використання даної ставки дисконтування. Той самий проект, реалізований під час інвестування дешевшого капіталу або з меншою необхідною прибутковістю, може дати позитивне значення чистого приведеного доходу, тобто:

- якщо $N P V>0$, то проект варто прийняти;

- якщо $N P V<0$, то проект потрібно відхилити;

- якщо $N P V=0$, то проект є ні прибутковий, ні збитковий.

За методом $N P V$ припускаємо, що всі потоки грошових коштів можуть бути реінвестовані за тією ж ставкою, за якою банк платить за користування капіталом.

Розрахунок чистого приведеного доходу здійснюють за формулою

$$
N P V=-I+\sum_{i=1}^{n} \frac{V_{i}}{(1+r)^{i}},
$$

де: $V_{i}$ - дохід у $i$-ий період; $I-$ величина початкової інвестиції; $r$ - ставка дисконтування; $n$ - кількість періодів (років, місяців і т. д.) $(n=1,2, \ldots)$.

За формулою (2) визначають додатних чи від'ємних значень набуває $N P V$ за умов, що всі величини $-I, V, r-$ не змінюються у часі. Але на практиці можна лише приблизно оцінити коефіцієнт дисконтування, грошовий потік і величини початкового інвестування. Як правило, наперед відомі лише найбільш ймовірні значення параметрів, а також їх максимальне і мінімальне значення. Такі ситуації оцінки інвестиційних проектів найбільш адекватно описує нечітка логіка.

Нечітка логіка не замінює традиційні методики управління, а навпаки долучається до них і розширює можливості традиційних методик. Переваги такого злиття базують на такому:

- формаліхзують і об'єднують досвід теоретиків і практиків;

- пропонують простий метод розрахунку складних процесів;

- постійно враховують досвід управління процесами цього типу з урахуванням особливостей системи;

- враховують різні вихідні дані, які об'єднуються.

Визначення виду функцій приналежності ( $\mu$-функцій) є одним із найважливіших питань у теорії нечітких множин (Semenenko, Kniazeva \& Cherniaev, 2013). Здебільшого використовують трикутні, трапецевидні, сигмоїдні функції, функції Гауса. Трикутні функції приналежності використовують переважно як навчальні приклади, а для практичних завдань бажано застосовувати функції Гауса.

Для задачі оцінки інвестиційного проекту скористаємось методикою $\alpha$-рівнів (Shtovba, 2018). Множиною $\alpha$-рівня нечіткої множини А називають звичайну множину, яка складається 3 усіх таких елементів універсальної множини U, для яких виконується нерівність $\mu_{A} \geq \alpha$, де $\mu_{A}-$ функція приналежності. Множини $\alpha-$ рівня часто використовують під час оперування з нечіткими множинами. Побудова множин $\alpha$-рівня дає змогу виконувати наближений розклад нечіткої множини.

Застосуємо методику $\alpha$-рівнів для розв'язування конкретної задачі. Величина інвестиційного проекту становить близько 3 млн дол. 3 можливими відхиленнями від 2,8 до 3,1 млн дол. Передбачено, що термін реалізації проекту становить 2 роки, в кожен 3 яких він має у середньому приносити дохід 2 млн дол. 3 можливими відхиленнями від 1,3 до 2,7 млн дол. Дослідимо проект на основі чистої вартості та внутрішньої дохідності. Вважатимемо, що прибуток щороку однаковий $V_{1}=V_{2}$.

Оскільки показники проекту не можна визначити точно, задамо їх як нечіткі параметри. Визначимо змінні, які будемо представляти у нечіткій формі. Це початкова інвестиція $I$, прибуток $V$, ставка дисконтування $r$. Вважатимемо, що ці показники змінюються на інтервалах у зазначених межах. Задамо для них функції приналежності у вигляді як трикутних функцій, так і функцій Гауса. Побудуємо множини $\alpha$-рівня. Оберемо 10 рівнів $\alpha$ на відрізку $\mu \in[0 ; 1]$, зробимо наближене розкладання нечітких множин $I, V, r$. Використовуючи операції з $\alpha$-рівнями, знайдемо $N P V$ і отримаємо наближене розкладання нечіткої множини $N P V$ за заданими рівнями.

Для початкової інвестиції $I$ та щорічного прибутку $V$ наближені значення задані в умові. Щоб визначити межі ставок дисконтування, знайдемо внутрішню дохідність проекту - ставку дисконтування, для якої значення чистої поточної вартості $N P V$ дорівнює нулю. На рис. 1 наведено графічний розв'язок, внутрішня дохідність становить $r=21,45 \%$.

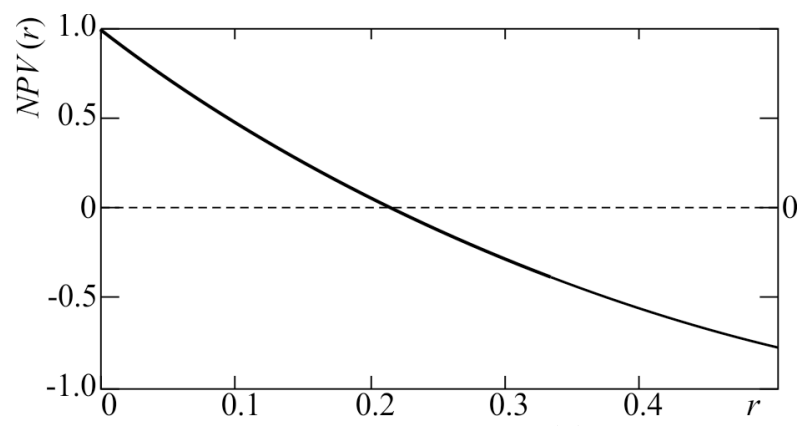

Рис. 1. Графічний розв'язок рівняння $N V P(r)=0$

Зрозуміло, що якщо величина $r$ показника внутрішньої дохідності перевищить розраховане значення 21,45 \%, то проект ніколи не буде прибутковим. Тому для проведення обрахунків приймемо, що показник $r$ має найімовірніше значення $17 \%$ та змінюється від 11 до $20 \%$.

Наведемо значення середньоквадратичних відхилень функцій приналежності Гауса для обраних $I, V, r$ :

$\sigma_{L, I}=0.081 ; \sigma_{R, I}=0.04 ; \sigma_{L, V}=0,28 ; \sigma_{L, r}=0.021 ; \sigma_{R, r}=0.016$.

Обчислимо значення лівих та правих границь $\alpha$-рівнів початкових інвестицій $-I$, щорічних прибутків $-V$, ставки дисконтування $-r$ та чистого приведеного доходу $N P V$ для трикутної функції приналежності та функції Гауса (Nyemkova \& Rusynko, 2015).

Графік функції $N P V \alpha$ представлено на рис. 2, а за трикутних функцій приналежності, 2, б- за функцій приналежності Гауса. За результатами аналізу масиву 
$N P V \alpha$ зробимо висновок, що проект є прибутковим для рівня $\alpha>0,7$ за трикутних функцій приналежності та прибутковим для рівня $\alpha>0,8$ за функцій приналежності Гауса.

Незначні відмінності у значеннях границь $\alpha$-рівнів трикутної функції приналежності та функції Гауса величин $I, V, r$ призвели внаслідок до зміщення рівня оцінки інвестиційного проекту від 0,7 до 0,8 . Значення $N P V \in$ в межах від $-0,574$ до 0,976 млн грн.

Якщо застосовувати для оцінки інвестиційного проекту трикутні функції приналежності, то очікуваний річний прибуток буде в межах від 1,86 до 2,14 млн дол. за ставки дисконтування від 15,8 до 17,8 \%. Це відбудеться за умов, що початкові інвестиції знаходяться у межах від 2,960 до 3,020 млн дол.
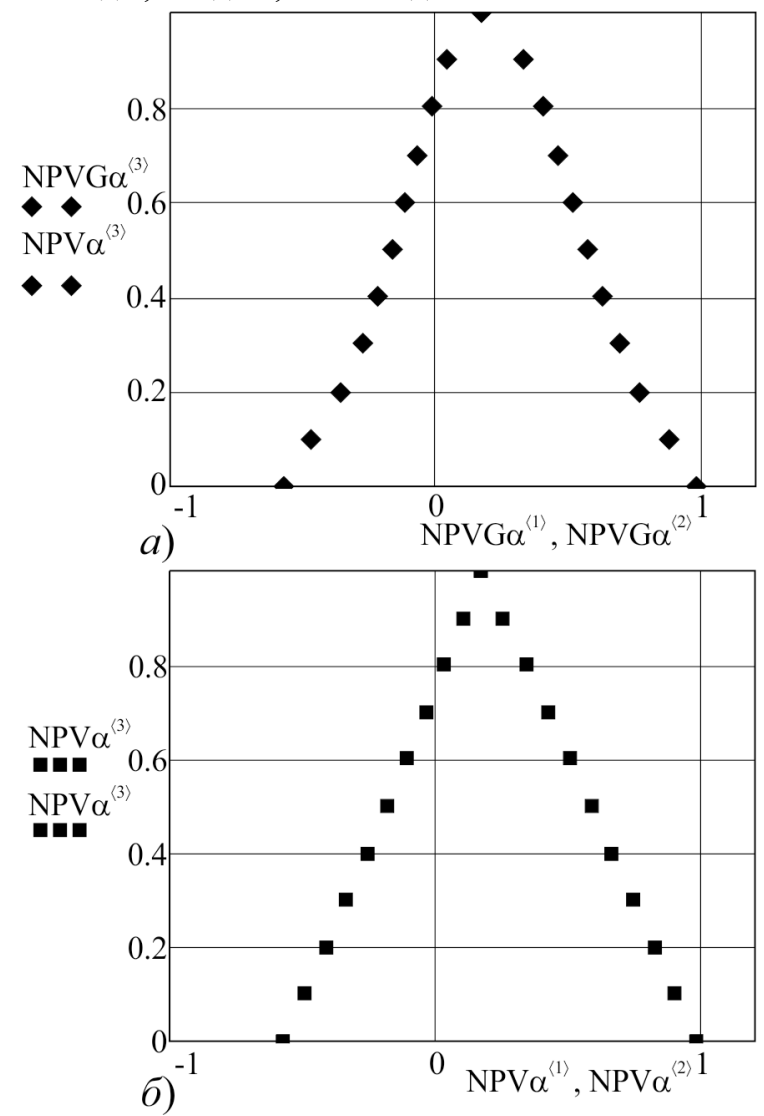

Рис. 2. Значення $\alpha$-рівнів для чистого приведеного доходу

Якщо застосовувати для оцінки інвестиційного проекту функції приналежності Гауса, то очікуваний річний прибуток можна знайти в межах від 1,87 до 2,13 млн дол. за ставки дисконтування від 15,9 до 17,7 \%. Це відбудеться за умов початкового інвестування у межах від 2,963 до 3,027 млн дол.

Отже, оцінка під час застосування функцій Гауса $€$ незначною, але чіткіше відрізняється від оцінки в разі застосування трикутних функцій, тобто вимагається більший обсяг початкових інвестицій, щоб проект був прибутковим.
Висновки. Запропоновано несиметричну функцію приналежності Гауса для використання методики $\alpha$-рівнів апарату нечіткої логіки. Несиметрія функції приналежності зумовлена специфікою побудови таких функцій для економічних показників, для яких у багатьох випадках можна зазначити тільки три значення: найімовірніше, мінімально та максимально можливі. Для розрахунку параметрів несиметричної функції Гауса спочатку побудовано наближення - трикутна функція приналежності. Виходячи з параметрів трикутної функції, розраховано середньоквадратичні відхилення для лівої та правої частин функції Гауса.

На конкретній задачі показано, що вид функції приналежності може впливати на результати обчислень. Проведено чисельні експерименти оцінки інвестиційного проекту на основі трикутних функцій приналежності та запропонованих несиметричних гаусоїд. У разі використання несиметричної функції Гауса потрібні більші кошти для початкових інвестицій для того, щоб проект був прибутковим. Пропонуємо застосовувати саме несиметричні функції Гауса під час проведення аналогічних розрахунків для зменшення ризику прогнозування.

\section{Перелік використаних джерел}

Chetyrkin, E. M. (2004). Finansovaia matematika. (4th ed.). Moscow: Delo, 400 p. [In Russian].

Eidinov, R. M. (2008). Matematicheskoe modelirovanie ekonomicheskikh i finansovykh situatcii. Ekaterinburg: Ural. gos. ekon. unta, 144 p. [In Russian].

Kane, E. J., \& Malkiel, B. G. (1965). Bank Portfolio Allocation, Deposit Variability and the Availability Doctrine. (Vol. 79). Quarterly Journal of Economics, 1(2), 113-134.

Murphy, N. B. (1972). Costs of Banking Activities: Interactions Between Risk and Operating Costs: A comment. Journal of Money, Credit and Banking, 8, 614-615.

Newman, P. (1987). Francis Ysidro Edgeworth (1845-1926). The New Palgrave: A Dictionary of Economics, (Vol. 2, pp. 85-98). Eds J. Eatwell, P. Newman \& M. Milgate. London: Macmillan, 320 p.

Nyemkova, E. A., \& Rusynko, M. K. (2015). Ocinka investyciinykh proektiv metodamy nechitkoi logiky dlya nesymetrychnykh funkcii prynalegnosty. Visnik Universitetu bankivskoi spravy, 2(23), 171177. [In Russian].

Porter, R. C. (1961). A model of Bank Portfolio Selection. Cowles Foundation Paper 168. Reprinted from Yale Economic Essays, 1(2), 323-359.

Semenenko, M. G., Kniazeva, I. V., \& Cherniaev, S. I. (2013). Problemy vybora funktcii prinadlezhnosti nechetkikh mnozhestv. Sovremennye problemy nauki i obrazovaniia, 5, 63-68. [In Russian].

Shtovba, S. D. (2018). Vvedenye $v$ teoryiu nechetkykh mnozhestv y nechetkuiu lohyku. Retrieved from: http://matlab.exponenta.ru/fuzzylogic/book1/index.php. [In Russian].

Sinki, Dzh. F. (1994). Upravlenie finansami v kommercheskikh bankakh. (4th ed.). In R. V. Levity, \& V. S. Pinskera (Eds.). Moscow: Saiaiiakhu, 982 p. [In Russian].

Yankovskyi, Yu. A. (2008). Henezys matematycheskykh modelei banka. Bankay̆ski vesnik, 2, 27-30. [In Russian].

Zamkov, O. O., Tolstopiatenko, A. V., \& Cheremnykh, Iu. N. (2001) Matematicheskie metody v ekonomike. (3rd ed.). Moscow: MGU im. M. V. Lomonosova, 368 p. [In Russian].

М. К. Русинко, Т. Н. Костырко Львовский учебно-научный институт ГВУЗ "Университета банковского дела", г. Львов, Украина

\section{МОДЕЛИРОВАНИЕ ИНВЕСТИЦИОННОЙ ПОЛИТИКИ БАНКА МЕТОДАМИ НЕЧЕТКОЙ ЛОГИКИ}

Проанализированы модели, используемые в банковской практике, начиная с работ Эджворта до моделей нечеткой логики. Указаны их преимущества и недостатки. Обоснован выбор модели нечеткой логики, как инструмента моделирования. Рассмотрена задача инвестиционной политики банка, для которой определен вид функции принадлежности, который является одним из наиболее важных вопросов в теории нечетких множеств. Функцией принадлежности избрана несимметричная 
функция Гаусса, что обусловлено спецификой построения таких функций для экономических показателей, для которых во многих случаях можно указать только три значения: наиболее вероятное, максимально и минимально возможные. Предложено использование несимметричной функции принадлежности, сформированной на основе функции Гаусса с разными значениями среднеквадратичного отклонения. Проведены численные эксперименты оценки инвестиционного проекта на основе треугольных функций принадлежности и предложенных несимметричных гауссоид. Для расчета параметров несимметричной функции Гаусса сначала построена приближенная модель с треугольной функцией принадлежности. Используя параметры треугольной функции, рассчитаны среднеквадратические отклонения для левой и правой частей функции Гаусса. Показано, что при использовании несимметричной функции Гаусса, начальные инвестиции должны быть более существенными, чем при треугольной, чтобы проект был прибыльным. Сделан вывод необходимости тщательного подбора вида функций принадлежности.

Ключевые слова: чистый приведенный доход; альфа-уровень; несимметричная функция принадлежности; инвестиции.

M. K. Rusynko, T. M. Kostyrko

Lviv Educational and Research Institute of Banking University, Lviv, Ukraine

\section{MODELING OF A BANK INVESTMENT STRATEGY BY FUZZY LOGIC'S METHOD}

Effective functioning of the country's economy, the pace and scale of its investment activity, partly extent depends on the state and development of the banking system. Therefore, the question of effective operation of the bank and the management of its capital is relevant to the realities of our time. Researching and solving problems of bank capital management, namely, its investment policy, require using of such economic and mathematical models, that considers both managed and unmanaged (risks, modelling faults, etc.) parameters. Among the models considered in this article, fuzzy logic models cover all of these factors. The considered methods of solving problems of banking capital management under conditions of uncertainty are based, primarily, on statistical models, when the knowledge of the probabilistic characteristics of the main parameters of the model is necessary. In addition, their use requires the fulfilment of strict conditions, which in practice are not fulfilled yet. Fuzzy logic does not replace the classical mathematical models of management; on the contrary, it extends the possibilities of traditional methods. In the course of study the authors have reviewed the investment project estimation task based on NPV with fuzzy logic methods, estimation with alpha-levels method, in particular. Determining the kind of belonging functions ( $\mu$ - functions) is one of the most important issues in the theory of fuzzy sets. We offer the use of asymmetric membership function formed on the basis of Gauss function with different standard deviation values. To calculate the parameters of the asymmetric Gaussian function, an approximation is constructed that is a triangular membership function. Based on the parameters of the triangular function, the mean-square deviations for the left and right parts of the Gaussian function are calculated. The expected annual profit of the investment project has been calculated and analysed in the application of the triangle and asymmetric Gaussian function. To summarise, the use of the asymmetric Gauss function requires more capital for initial investment, so that the project is profitable. Numerical evaluation of investment project has been done based on triangular membership functions and asymmetric gaussoids are offered. A conclusion about the necessity of thorough membership function selection for investment risk reduction has been made.

Keywords: NPV; alpha-levels; asymmetric membership function; investment. 